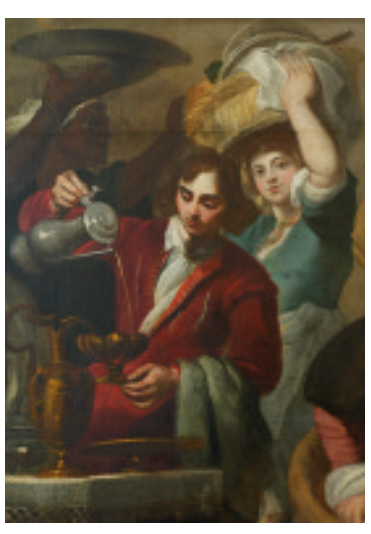

Detalle de El convite de Jesús en casa de Simón el Fariseo afectado principalmente a la mitad izquierda del cuadro. Además, el soporte presentaba numerosas roturas (siendo la principal la que atravesaba el lienzo de arriba abajo dividiéndolo casi en dos mitades), desprendimientos y pérdida de la capa pictórica sobre todo en los ropajes color ocre de la figura femenina central.

Tras la llegada de El Convite del Fariseo a los talleres del IAPH, la obra fue sometida a un tratamiento de desinsectación. A continuación se sustituyó el antiguo reentelado por otro nuevo y se colocaron injertos de lino en las faltas de lienzo, construyéndose también otro bastidor.

En cuanto a la actuación sobre la superficie pictórica se han eliminado la capa de barniz oxidado, los estucos y los repintes degradados para recuperar así los colores originales. En aquellas zonas en las que se había perdido pintura se ha procedido a una reintegración cromática mediante la técnica de rigattino, que permite establecer una diferenciación tonal entre la aplicación original y los retoques.

Este impresionante cuadro de Miguel Manrique permaneció expuesto en el Palacio Episcopal de Málaga hasta el pasado 12 de marzo, acompañado de una serie de paneles explicativos que recogían todo el proceso de intervención.

El conservador de pintura flamenca del Museo del Prado Matías Díaz Padrón pronunció el pasado 2 de marzo una conferencia acerca de la influencia de Rubens en la pintura española, y el día 10 de marzo la restauradora del IAPH, Amalia Cansino Cansino, responsable de la restauración, y el historiador del arte Gabriel Ferreras Romero fueron los encargados de explicar los trabajos de restauración de la obra.

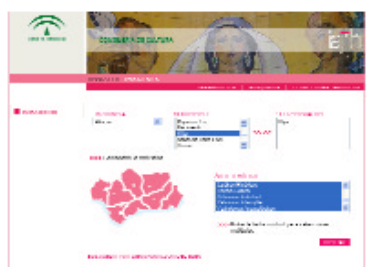

\title{
Nuevo Banco de Imágenes en el portal web del IAPH
}

Dentro de la filosofía de renovación y diseño del nuevo portal web del IAPH, el Banco de Imagen digital ha sufrido una importante transformación en cuanto a estructura y volumen de contenido.

Desde su constitución, el Departamento de Técnicas de Documentación Gráfica del Centro de Documentación ha tenido entre sus objetivos prioritarios la creación, custodia y difusión del Banco de Imagen en soporte digital. Este proyecto del Instituto Andaluz del Patrimonio Histórico nació de la necesidad de documentar gráficamente el Patrimonio Histórico de Andalucía y se ha nutrido progresivamente con imágenes de producción propia de la Consejería de Cultura o mediante adquisiciones y donaciones de particulares e instituciones.

El IAPH potenció desde un principio el desarrollo de la imagen digital a través de campañas fotográficas sistemáticas para documentar dicho patrimonio. Asimismo, desde hace unos años se realizan trabajos de digitalización y tratamiento de las imágenes analógicas, generadas desde el nacimiento de nuestra administración cultural con el fin de facilitar la gestión interna de la información y evitar la manipulación de los originales. Estos trabajos, realizados por un equipo interdisciplinar, constituyen una herramienta fundamental para la conservación, difusión y gestión administrativa de nuestro Patrimonio Cultural.

Salvando muchas dificultades a lo largo de estos años hemos avanzado progresivamente en las técnicas de captura y formatos de imágenes digitales, buscando siempre la máxima calidad dentro de las posibilidades que las nuevas tecnologías nos han ofrecido.
Del fondo gráfico del IAPH, que en la actualidad cuenta con más de 45.000 documentos gráficos en formato digital, presentamos en esta nueva etapa del Banco de Imagen un volumen sustanciosamente mayor de documentación gráfica (2.200 imágenes) del Patrimonio Inmueble de Andalucía que se ha organizado por áreas temáticas dentro de una estructura territorial de provincias y municipios. Las herramientas de búsqueda están pensadas para satisfacer y cubrir un amplio espectro de posibilidades. Periódicamente esta selección de imágenes se irá renovando y ampliando a otras tipologías patrimoniales.

Como novedad hemos introducido una sección denominada "Colecciones temáticas". Estas colecciones de imágenes tendrán una variada temática centrada en el rico y extenso Patrimonio Cultural de Andalucía. El volumen y la organización de la documentación contenida en estas series monográficas dependerán de la singularidad y características del tema tratado.

Iniciamos esta sección con una colección denominada "Écija ciudad histórica". En ella se muestra una selección de imágenes del patrimonio inmueble de esta singular ciudad andaluza. En los próximos meses ampliaremos esta sección con monografias dedicadas al patrimonio mueble e inmaterial de Andalucía.

Carmen Pizarro Moreno

Isabel Dugo Cobacho

Centro de Documentación del IAPH 